TITLE:

\title{
ON A MICROSCOPIC PHASE IN THE LIFE CYCLE OF NEMALION PULVINATUM GRUNOW (NEMALIONACEAE, RHODOPHYTA)
}

\author{
$\operatorname{AUTHOR}(\mathrm{S}):$ \\ Umezaki, Isamu
}

\section{CITATION:}

Umezaki, Isamu. ON A MICROSCOPIC PHASE IN THE LIFE CYCLE OF NEMALION

PULVINATUM GRUNOW (NEMALIONACEAE, RHODOPHYTA). PUBLICATIONS OF THE SETO MARINE BIOLOGICAL LABORATORY 1967, 15(4): 311-318

ISSUE DATE:

1967-12-20

URL:

http://hdl.handle.net/2433/175472

RIGHT: 


\title{
ON A MICROSCOPIC PHASE IN THE LIFE CYCLE OF NEMALION PULVINATUM GRUNOW (NEMALIONACEAE, RHODOPHYTA) ${ }^{1)}$
}

\author{
ISAMU UMEZAKI \\ Department of Fisheries, Faculty of Agriculture, Kyoto University, Maizuru
}

With Plates VIII-X and 4 Text-figures

Nemalion pulvinatum Grunow (Nemalionaceae, Rhodophyta) is a taxonomically problematical species. Recently, Miss B. T. CHIU (1961) reported that Nemalion pulvinatum should be placed as a species of Dermonema. I continue to use the name Nemalion pulvinatum, because its complete taxonomy is not yet treated. Previously, the general life history of Nemalionaceae had been thought to be haplobiontic since Svedelius (1915) and Kylin (1916) showed that the zygote nucleus in Scinaia and Nemalion respectively underwent meiosis. Recently, MAGNE (1961a, 1961b; 1964a, 1964b) reported new facts concerning the nuclear cycle of the family, rectifying earlier statements of Svedelius, Kylin and others. He found that in Lemanea, Nemalion and Scinaia the fertilized carpogonium did not undergo meiotic division. Von STOSCH (1965) in his cytological and culture studies of Liagora farinosa demonstrated MAGnE's theory: that is, the species showed a heteromorphic life history and its carpospore germlings gave rise to presumed sporophytes represented by microscopic phase. MARTin (according to a copy of her manuscript) also observed that carpospores of Nemalion elminthoides in culture developed into creeping filaments bearing monospores and that exactly similar creeping filaments from the sea gave rise to Nemalion plants.

In order to investigate the life cycle of Nemalion pulvinatum I cultured the carpospores and observed that they gave rise on germination to Acrochaetium-like filaments bearing monosporangia and that the presumed sporophyte reproduced repeatedly by monospores for a certain period. No tetrasporangia have been observed on these plants.

\section{Materials and Methods}

Fertile plants of Nemalion pulvinatum were collected on May 22, 1966 and on April 20, 1967 from Shirahama, Wakayama Prefecture, where they are common from April to June. The plants collected were brought to the Department of Fisheries,

1) Contributions from the Seto Marine Biological Laboratory, No. 477.

Publ. Seto Mar. Biol. Lab., XV (4), 311-318, 1967. (Article 19) 
Faculty of Agriculture, Kyoto University at Maizuru, where this study was carried out. The plants are dioecious. The female plants were cut into about $5 \mathrm{~mm}$ length and washed carefully in sterilized sea water to eliminate epiphytic diatoms and other microorganisms. One or two cleaned pieces were put in a watchglass containing the sterilized sea water. After five to ten hours carpospores were found discharged in the watchglass. The discharged spores were transferred to slide-glasses placed on the bottom of a Petri dish containing culture medium. On the following day the slide-glasses to which young germlings attached were transferred to a glass dish containing $500 \mathrm{ml}$ of medium. The enriched sea water media, SWII and ASW8, which were beforehand sterilized by heating for half an hour at $75^{\circ} \mathrm{C}$, were employed for the present culture. Both media were suitable for the growth of sporophytes. The medium was changed weekly. All the apparatus used were sterilized in an electric sterilizer for two hours at $160^{\circ} \mathrm{C}$. In 1966 , cultures had been controlled under these conditions: 24 hours illumination daily of day light fluorescent lamps (about 1000 lux) at room temperature, for a week after spore germination or from May 24 to June 1 ; and 8 hours illumination daily of day light fluorescent lamps (about 500 lux) at 20 $22^{\circ} \mathrm{C}$, for two months or from June 2 to August 1. Cultures started in 1967 were given continuous illumination of day light fluorescent lamps (about 500 lux) at $2 \mathrm{l}-22^{\circ} \mathrm{C}$, after germination.

\section{Observations}

Discharged carpospores were naked for a while and showed amoeba-like movements. A few hours later they became attached to slides and enveloped in a colorless thin membrane. They were spherical with a stellate chromatophore and measured 12.5-17 $\mu$, mostly $15 \mu$ in diameter. Within a day nearly all of the spores began to germinate. Two modes of spore germination were observed. In the one mode, the spore produced a protuberance and the whole protoplasm of the spore moved to the elongated protuberance or germ tube. (Fig. 1, a-i; Pl. VIII, fig. 1). In the other one, even after the elongation of a protuberance the protoplasm of the spore remained there and its spore body functioned as a living cell after that. (Fig. 1, $a^{\prime}-d^{\prime}$ ). The former appeared to be an usual type for the species, although the latter were sometimes found in high frequency. The former is INoH's "typus filamentosus mediatus" (1947) or Kylin's "Keimschlaus-Typus" (1917) and the latter INoH's "typus filamentosus immediatus". There was no distinction in regard to the subsequent development of filaments between the two types. When the germ tube lengthened two or three times as long as the spore body, one wall separated the spore body from the germ tube. In the former type, the emptied spore body disappeared early, but sometimes persisted, attaching to the filament even at its fertile stage. Five to ten days later most of the germlings became nearly ten-celled filaments on which one or two laterals were produced. These filaments all had one or two hairs on them. The hair was colorless, $1.0-1.5 \mu$ broad, $100 \mu$ long or more, and with protoplasm 


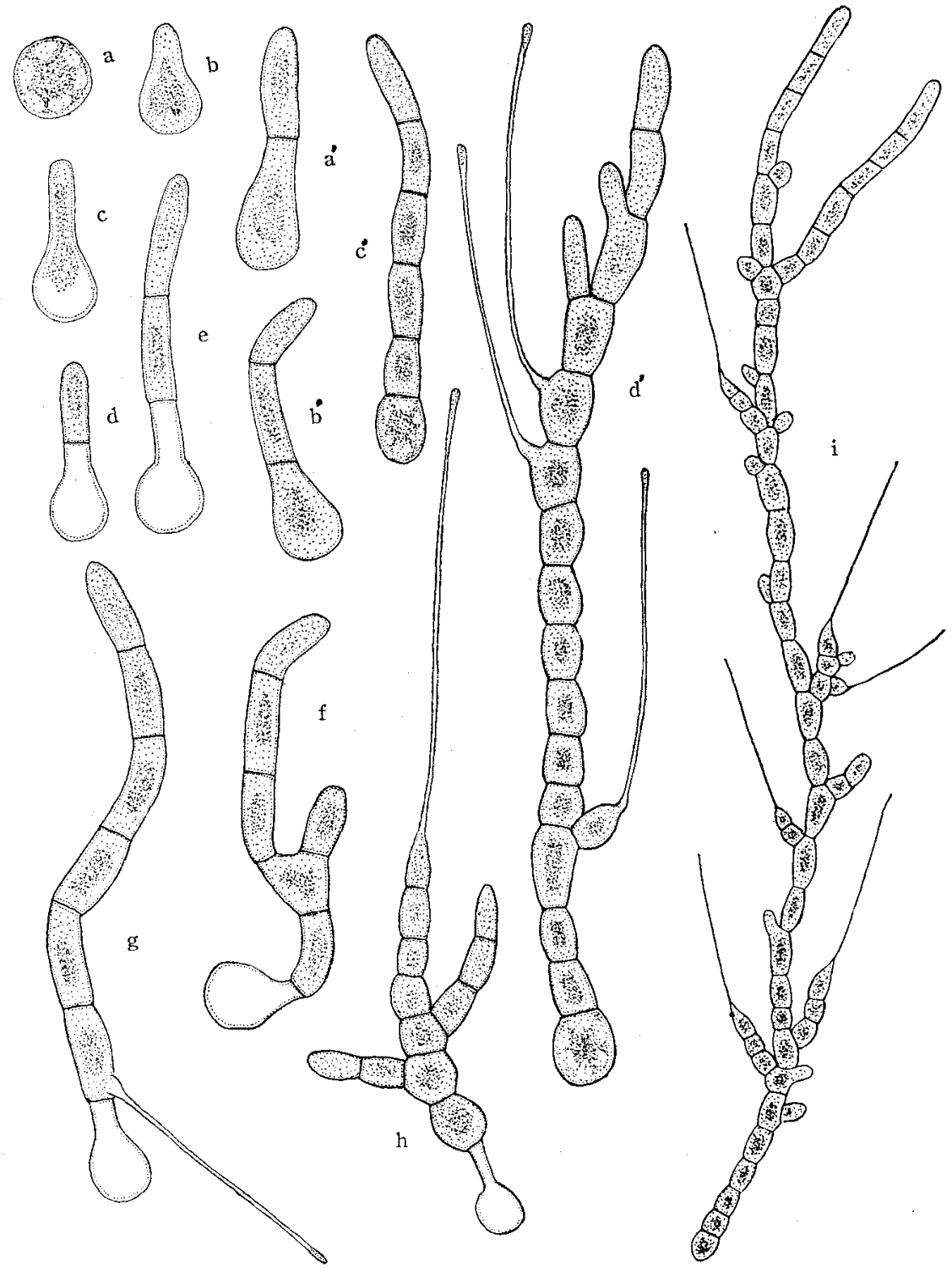

Fig. 1. Various stages in development of germlings from carpospores. a-i, after germination the protoplasm of the spore is moved to the germ tube. $a^{\prime}-d^{\prime}$, the protoplasm of the spore is remained the spore body. a-h, $a^{\prime}-d^{\prime} . \times 330 ;$ i. $\times 145$.

only at its tip. (Fig. 1, g-h; Pl. VIII, figs. 2-3). It showed much the same features as that of Acrochaetium species. After twenty days to one month the germlings developed into well branched filaments with hairs and became $1 \mathrm{~mm}$ or more in length, the habit closely resembling a species of Acrochaetium. (Fig. 1, i; Fig. 2; Pl. VIII, fig. 4). The Acrochaetium-like filaments usually creep on the substratum, but some- 
times their laterals or terminals became upright and branched freely. They did not develop into a heterotrichous habit. When cultured in continuous light the Acrochaetium-like filaments reached a length of $3 \mathrm{~mm}$ to $5 \mathrm{~mm}$ two months after germination and were best developed under these conditions. In cultures of the year 1966 the filaments became fertile and produced monosporangia on July 1 or 30 to 37 days after germination. In 1967, monosporangia formation and release of fertile monospores occurred on May 18 or 20 to 25 days after germination. Both the cultures of 1966 and 1967 produced monosporangia successively, and released monospores for about one month or a little more under the same conditions. Sessile monosporangia were born laterally on the nearly basal or middle cells of the filament, or terminally or laterally on the short branches of one, two, or three

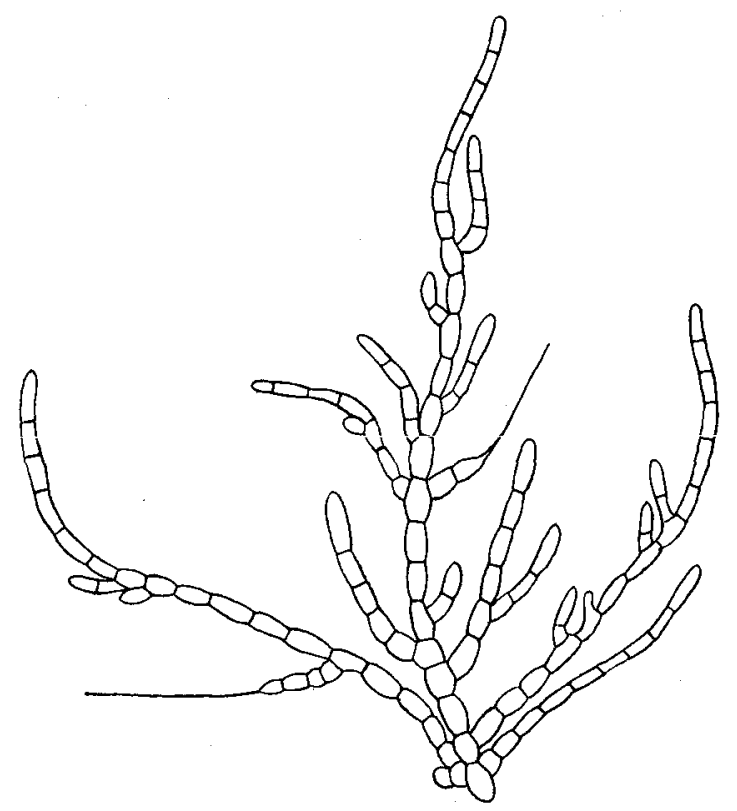

Fig. 2. Well developed filament from a carpospore. $\times 100$.

cells. They are $10-15 \mu \times 12.5-17.5 \mu$ in size, hemispherical, short clavate or conical in side view. (Fig. 3; Pl. IX, fig. 1-4). The sporangium is enveloped in the wall composed of three layers: the outer layer is a membrane of the filament itself, being burst at its apex; and the middle and inner layers appear to be a membrane secreted from the sporangium itself. The monospores were liberated by rupture of the apex of the sporangium wall. The naked monospores showed amoeboid movements like carpospores for a while after liberation. After a few hours the spores fixed to slides and were enveloped in a colorless membrane. They were $12.5-16 \mu$ in diameter, the size being equal to that of carpospores. Immediately the spores began to germinate and developed into the Acrochaetium-like filaments. 


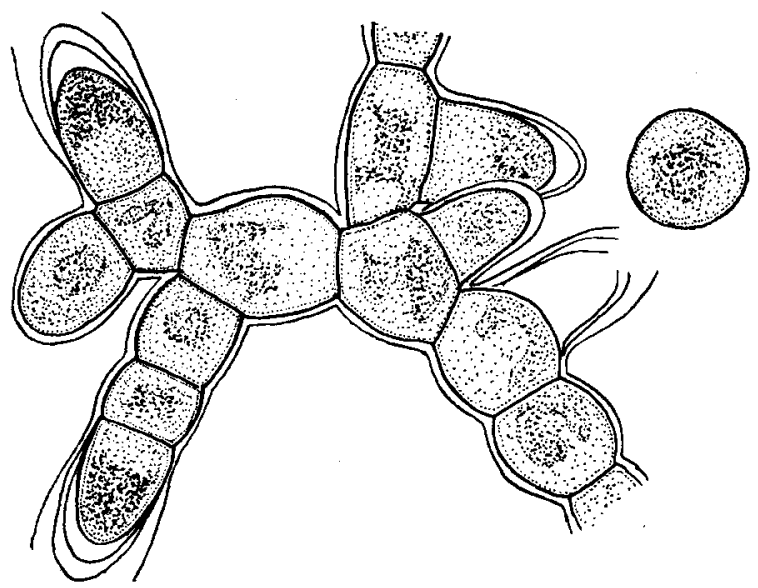

Fig. 3. Part of a filament showing two well developed monosporangia and liberation of a monospore. $\times 600$.

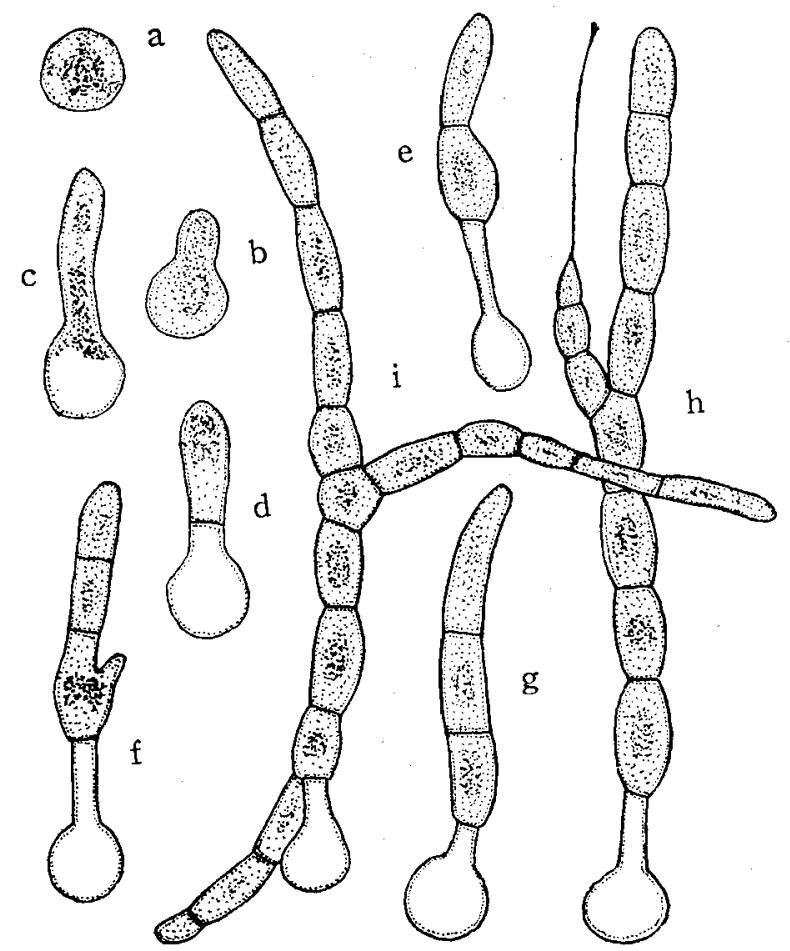

Fig. 4. Monospore and its germlings showing various stages in development. $\times 300$. 
(Fig. 4; Pl. X, figs. 1-2). The germination mode was much the same as that of carpospores. After a monospore was released, sometimes a secondary new one was found produced within the emptied sporangium wall. Monosporangia on the same filament had been successively produced for a month or a little more. When these monospore germlings had been cultured under the same condition, they again grew fertile sporophytes bearing monosporangia in a month after germination. However, under these conditions no tetrasporangia have been formed on the Acrochaetium-like filaments, even in long continuous cultures.

\section{Discussion}

By Svedelius's cytological investigation on Scinaia (1915) and Kylin's on Nemalion (1916) the Nemalionaceae has hitherto been believed as having haplobiontic life cycle, although some exceptions were found. That is, meiosis occurred in the fertilized carpogonium so that the carposporophytes and the carpospores were thought to be haploid. However, MAGne's recent cytological investigations (1961a, 1961b; 1964a, 1964b) overthrew such previous opinions and showed that in some genera of Nemalionaceae carpospores as well as carpospore germlings were diploid. Moreover, Von STosch's (1965) research confirmed MAGNE's results: that is, Liagora farinosa, a species of Nemalionaceae, alternates the haplobiontic gametophyte with the diplobiontic sporophyte represented by a microscopic phase. MARTIN (according to a copy of her manuscript) observed also that creeping sporophyte filaments of Nemalion elminthoides in the field gave rise to gametophytes. In additon, sporophytes of Liagora farinosa and Nemalion elminthoides reproduced asexually by monospores, according to Von Stosar (1.c.) and Martin (1.c.), respectively. Acrochaetium species bearing monosporangia, which grew on Liagora had been collected by Аввотт (1962). Von STosah (1.c.) collected also same Acrochaetium bearing monosporangia growing on Liagora. These collections suggest that Acrochaetium-like plants bearing monospores in field may be derived from certain species of Nemalionaceae. And, the sporophytes of Liagora farinosa (Von Stosch, 1.c.), Nemalion elminthoides (Martin, 1. c.) and Nemalion pulvinatum (present study) appear to reproduce by monospores for a certain season, although the stage may not be an essential part of the life cycle of these species like tetrasporophytes.

\section{Summary}

1. Carpospores of Nemalion pulvinatum gave rise on germination to the Acrochaetium-like filaments.

2. The Acrochaetium-like filaments became sporophytes bearing monosporangia.

3. The sporophytes reproduced repeatedly by monospores for a certain period.

4. It has been known that Nemalion pulvinatum alternates the macroscopic 
gametophyte with the dwarf Acrochaetium-like sprophyte, although no tetrasporophyte has been observed.

\section{Acknowledgments}

I wish to express my sincere gratitude to Dr. I. A. Аввотт of the Hopkins Marine Station of Stanford University, Pacific Grove, for her careful reading of the manuscript. I also wish to thank Dr. M. T. MARTin of the University College of North Wales, Bangor, for sending me a copy of her manuscript.

\section{REFERENCES}

Aввотт, I. A. 1962. Some Liagora-inhabiting species of Acrochaetium. Occ. Pap. B. P. Bishop Mus., Honolulu, Hawaii, 23(6): 77-120.

Chru, B. T. 1961. (Quoted from I. A. Аввотт's Helminthora and Helminthocladia from California. Hydrobiol. 25: 88-98, 1965).

InoH, S. 1947. Germinations of seaweed species. 255 pp., Tokyo. (In Japanese).

Kylin, H. 1916. U̇ber die Befruchtung und Reduktionsteilung bei Nemalion multifidum. Ber. deutsch. bot. Ges. 34: 257-271.

—_ 1917. Über die Keimung der Florideensporen. Arkiv f. Botanik. 14: 1-25.

Magne, F. 1961a. Sur le cycle cytologie du Nemalion helminthoides (Velley) Batters. Compt. R. Acad. Sci. Paris, 252: 157-159.

- 1961b. Sur la caryologie de deux Rhodophycées considérées jusqu'ici comme à cycle cytologique entièrement haplophasique. Compt. R. Acad. Sci. Paris, 252: 4023-4024.

(1961). Proc. P. 112-116.

___ 1964b. Recherches caryologie chez les Floridées (Rhodophycées). Cah. Biol. Mar. 5: 461671.

Martin, M. T. (In Press). Observations on the life-history of Nemalion helminthoides (Vell. in With.) BATt.

Svedelius, N. 1915. Zytologisch-entwicklungsgeschichtliche Studien über Scinaia furcellala, ein Beitrag zur Frag der Reduktionsteilung der nicht tetrasporenbildenden Florideen. Nov. Acta Reg. Scient. Ups. ser. 4, 4: 1-55.

Von Stosch, H. A. 1965. The sporophyte of Liagora farinosa Lamour. Br. Phycol. Bull. 2(6) : 486-497. 


\section{EXPLANATION OF PLATES VIII-X}

Plate VIII. 1, carpospores and their germinations. $\times 310.2$, carpospore germlings in three day culture. $\times 310.3$, carpospore germling bearing a hair. $\times 310.4$, carpospore germling bearing monosporangia. $\times 35$.

Plate IX. 1-2, part of a sporophyte bearing monosporangia and germling from a monospore. $1 \times 200 ; 2 \times 310$. 3 , well matured monosporangium on a filament and germling from a monospore. $\times 460.4$, emptied three monosporangia from each of which monospore liberated. $\times 270$.

PLATE X. 1, monospores and their germlings are found near sporophytes from which monospores liberated. $\times 100.2$, three germlings from monospores. $\times 200$. 
Publ. Seto Mar. Biol. Lab., XV (4), 1967.

PLATE VIII
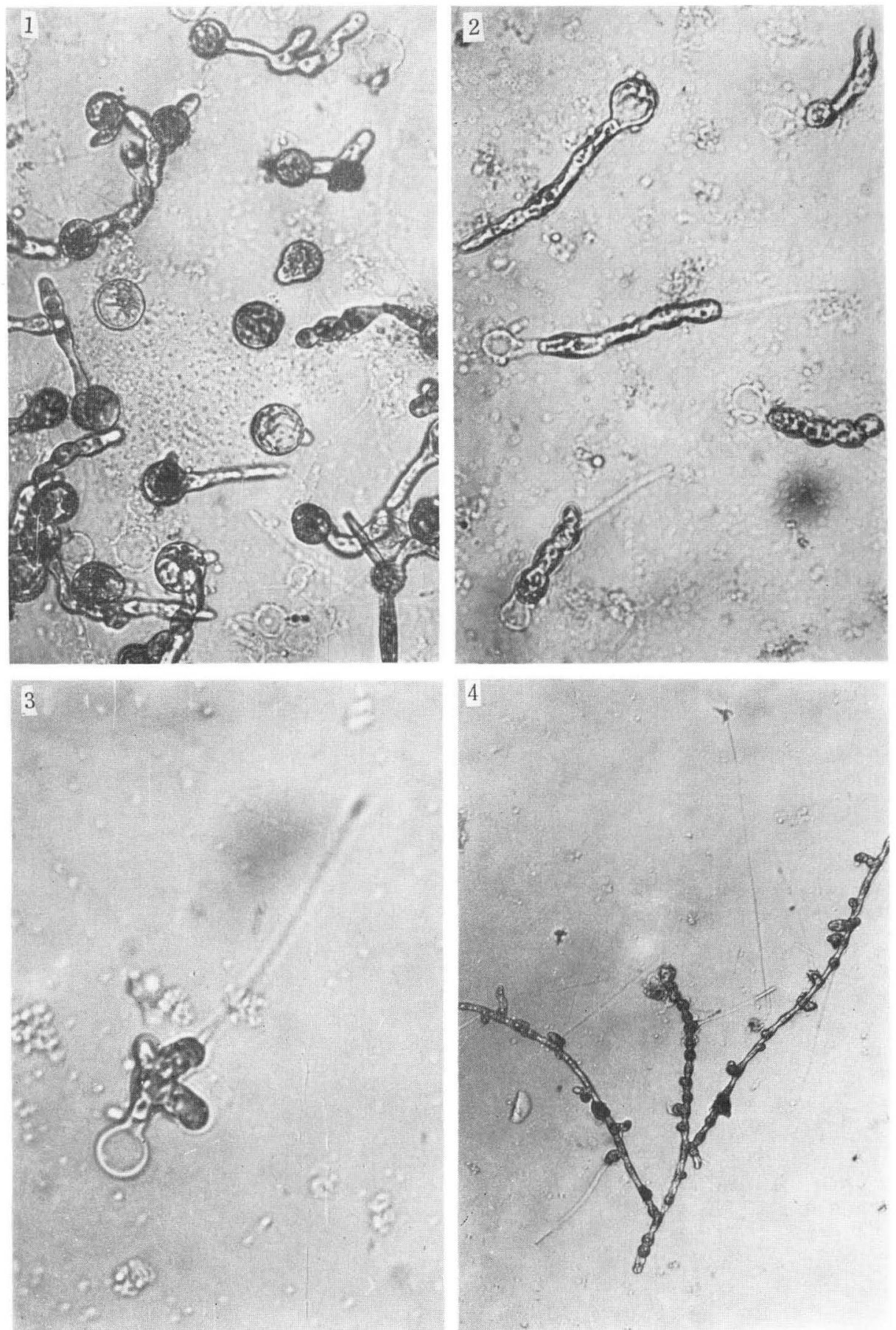

I. Umezaki: Microscopic Phase of Nemalion pulvinatum 

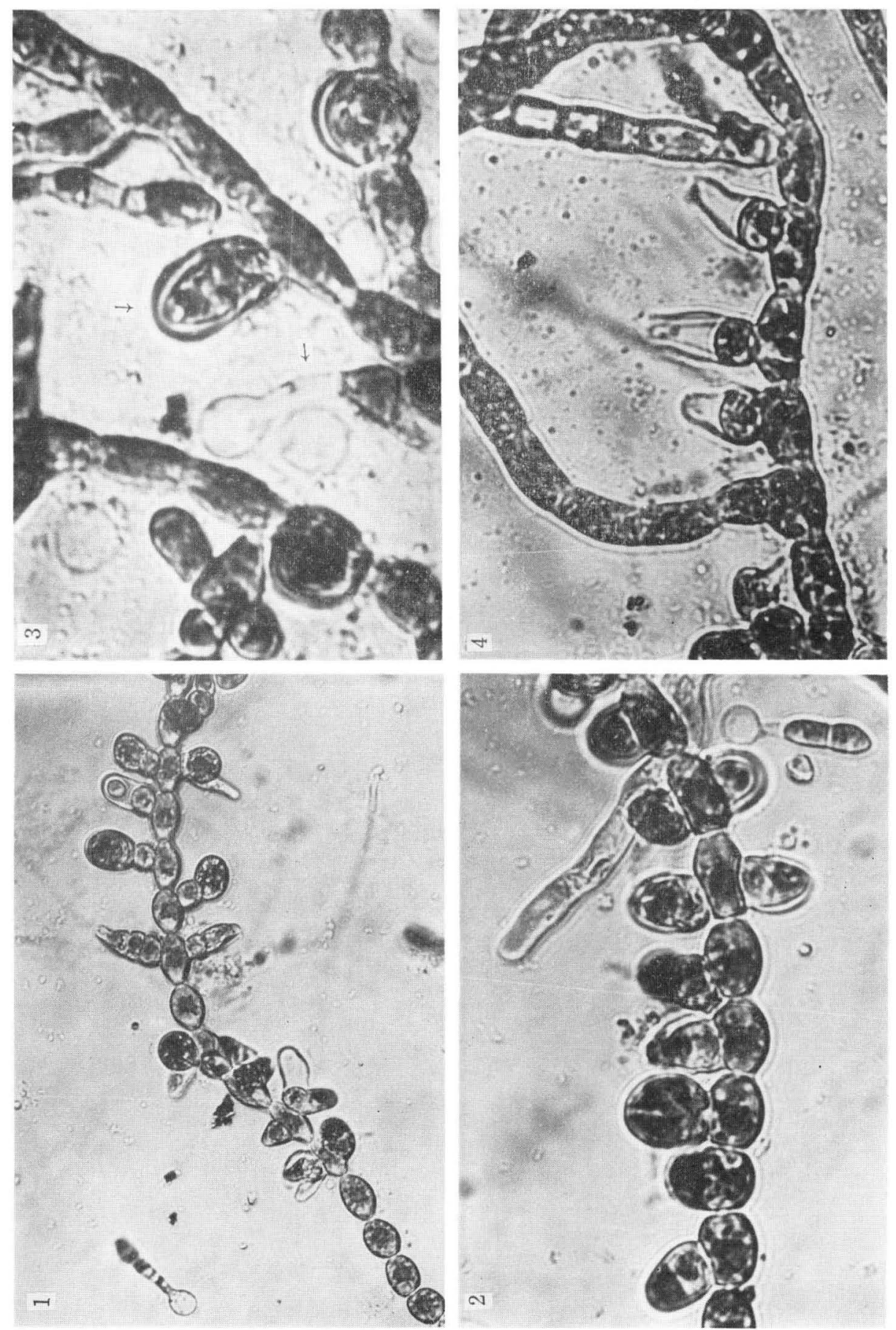

I. Umezaki: Microscopic Phase of Nemalion pulvinatum 
Publ. Seto Mar. Biol. Lab., XV (4), $1967 . \quad$ PLATE X

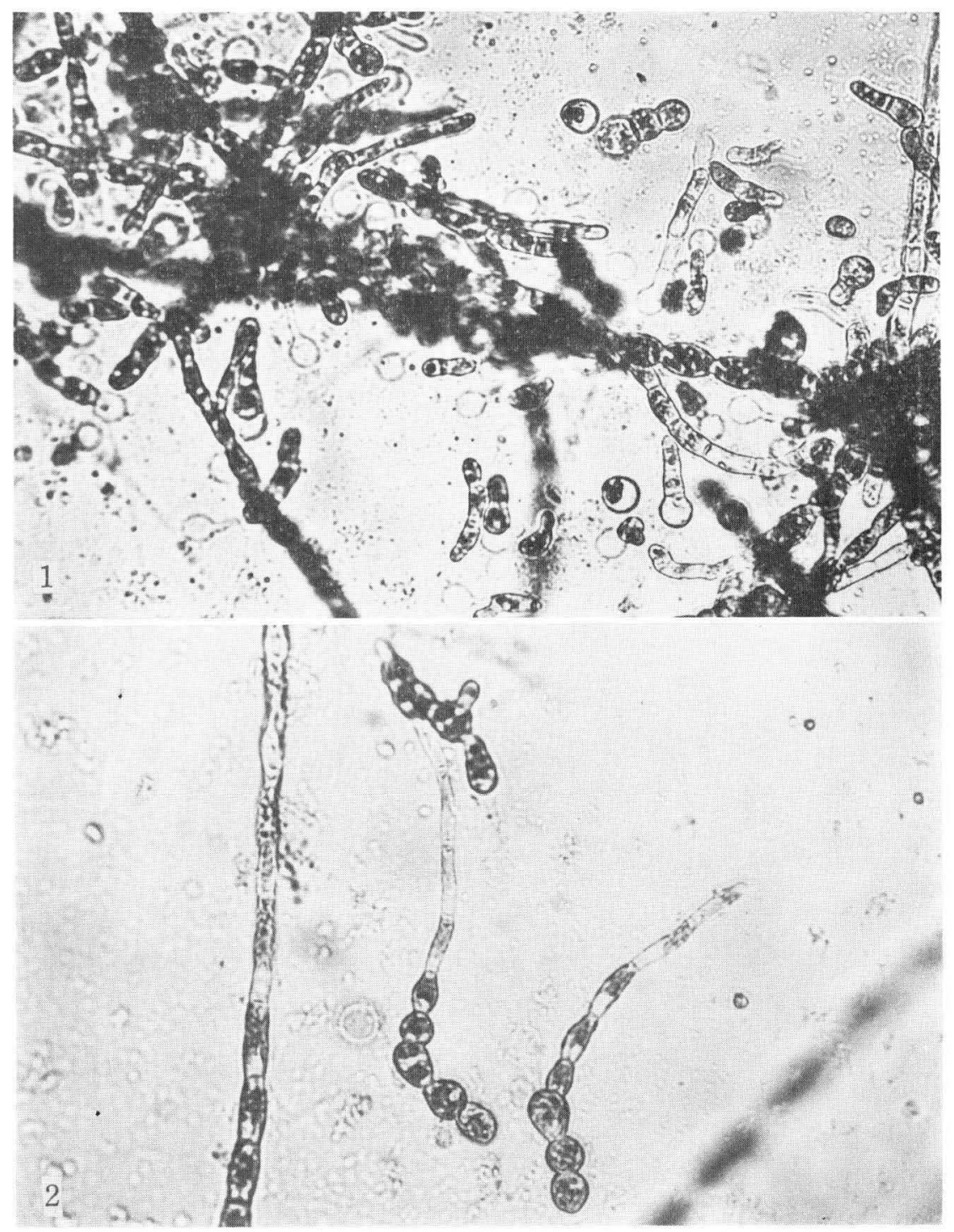

I. Umezaki: Microscopic Phase of Nemalion pulvinatum 